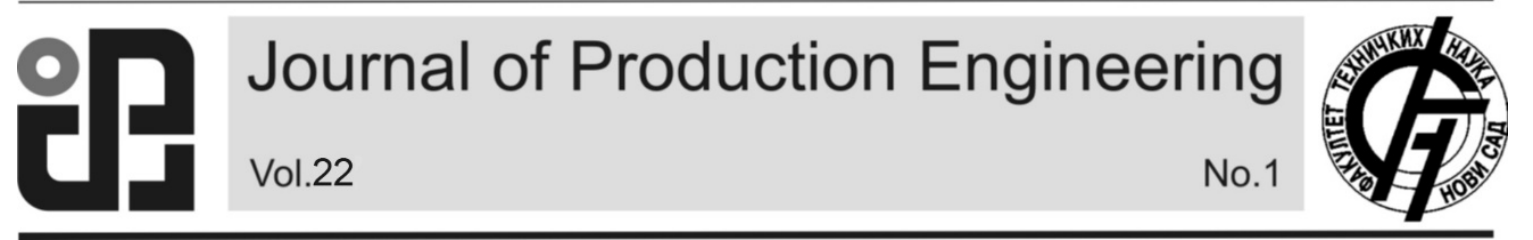

JPE (2019) Vol.22 (1)

Kovač, P., Savković, B., Rodić, D., Ješić, D.

Original Scientific Paper

\title{
THE CORRELATION OF TOOL WEAR PARAMETERS WITH MACHINING PROCESS PARAMETERS
}

Received: 15 January 2019 / Accepted: 27 April 2019

\begin{abstract}
In the paper is determined correlations between tool wear parameters and face milling process machinability parameters: cutting temperature, cutting forces and surface roughness according simultaneous measurements. Organization of measurements gave possibilities for obtaining simultaneously progress of all investigated parameters versus cutting time until tool is worn for chosen cutting conditions and modeling correlations among them.
\end{abstract}

Key words: cutting temperature, cutting forces, surface roughness, tool wear parameters.

Korelacija parametara habanja i parametara obradljivosti pri procesu obrade. $U$ radu su određene korelacije između parametara habanja pri čeonom glodanju i parametara obradljivosti: temperatura rezanja, sila rezanja, parametara hrapavosti obrađene površine na osnovu istovremenog merenja. Organizacija merenja pruža mogućnost da se istovremeno izmeri porast sa vremenom svih ovih parametara za izabrane režime rezanja sve do zatupljena alata I tako odredi njihova međusobna korelacija

Ključne reči: temperatura rezanja, sila rezanja, hrapavosti obrađene površine, parametari habanj aalata.

\section{INTRODUCTION}

The machinability parameters of the machining process are: cutting temperature, cutting forces and surface roughness. These parameters determine tool life, quality and economics of machining process as well. On some of these parameters are usually based sensors for machining process monitoring. Obviously, it is very important to determine correlations among them.

Modeling of the output responses: surface roughness, cutting force, cutting power, specific cutting force and metal removal rate during the face milling with software ANOVA was used for evaluating the influence of the cutting regime parameters, namely: cutting speed, feed per tooth and depth on the cut.

Output machining process responses in [1]. Besides well-established AI techniques, ensemble methods in [2] simultaneously use several AI models, where all the predictions are combined. The high accuracy of ensemble predictions has been demonstrated in many milling processes. Paper [1] proposes a method for cutting parameters identification using the multi-inputsmulti-outputs fuzzy inference system. The fuzzy inference system was used to identify the initial values for cutting parameters (cutting speed, feed rate and depth of cut) and flank wear using cutting temperature and tool life as outputs. Whenever the tool wear reaches a point where the design surface roughness cannot be attained or the tool wear approaches maximum values, forced cutting tool replacement is necessary. In this case, the direct method of controlling tool wear is used. When the tool wear approaches maximum values, forced cutting tool replacement is necessary. In this case, the direct method of controlling tool wear is used [2].
A Mechanistic model for prediction of the force system in face milling operations was determined in [3].

A combination of signal processing techniques to obtain improved and robust estimates of tool wear used [4]. In paper [3] demonstrated was the use of a probabilistic neural network in monitoring tool wear in the end-milling operation via acoustic emission and cutting power signals. The use of artificial intelligence methods is suggested in paper [5] for real-time prediction of surface roughness deviations, depending on the main drive power, and tool wear parameter, VB into account. A series of artificial intelligence methods are tested: random forest, standard Multi-layer perception's [3].

Regression Trees, and radial-based functions. Random forest was shown to have the highest model accuracy, followed by regression trees.

\section{EXPERIMENTAL METHOD}

For simultaneously measurement of machinability parameters acquisition system was arranged, Figure 1.

Work material was č 1730 (ASI 1060) The bar of this steel was fixed on the two Kistler piezoelectric platforms. This way it was possible to measure three orthogonal cutting force components on every point of the steel bar. A single tooth face milling cutter of 125 mm diameter with hard metal P 25 SPAN 1203 ER was used.

Cutting temperature was measured was performed by standard $\mathrm{CrNi}-\mathrm{Ni}$ embedded thermocouple in hard metal insert seat.

The increase of cutting temperature versus time is even approximately the same regardless of the measuring point, since the curves of the temperature of 
measuring point in cutting zone have are approximately parallel among themselves [6]. For practical realization of measurement, it is simplest way to trace the temperature on carbide insert support surface. Detail of temperature measurement is on Figure 2.

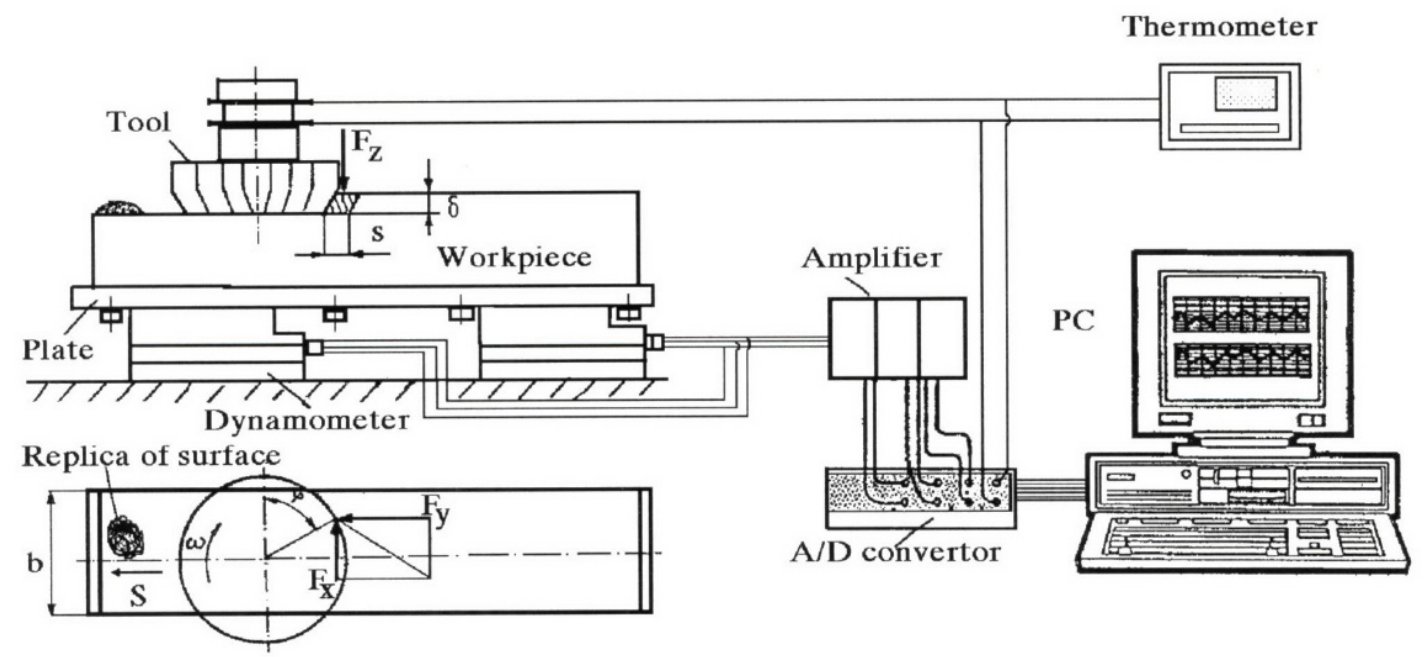

Fig. 1. Experimental arrangement in face milling

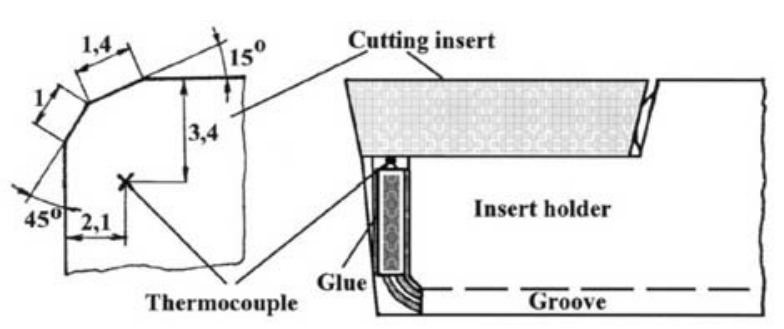

Fig. 2. Detail of temperature measurement

Surface roughness parameters were measured on the Perthometer from the replica of machined surface. Tool wear parameters were measured on tool light microscope. The cutting force signal from dynamometers after amplifier were transmitted through AD converter to PC. The measured signal from thermocouple were transmitted from virtual instrument to $\mathrm{PC}$ as well. The measured value of forces and temperature were processed and stored to PC.

The experimental research was carried out for different combination of cutting speed (v) feed per tooth (f) and depth of cut (a) according central composition plan of experiment, Table 1 .

\begin{tabular}{|c||r|r|r||}
\hline $\mathrm{C} \mathrm{C}$ & \multicolumn{1}{|c|}{$\mathrm{v}$} & \multicolumn{1}{c|}{$\mathrm{f}$} & \multicolumn{1}{c|}{$\delta$} \\
\hline $\mathrm{No}$ & $\mathrm{m} / \mathrm{s}$ & $\mathrm{mm} /$ tooth & \multicolumn{1}{c|}{$\mathrm{mm}$} \\
\hline \hline 1 & 1.83 & 0.22 & 1.5 \\
\hline 2 & 2.95 & 0.22 & 1.5 \\
\hline 3 & 4.65 & 0.22 & 1.5 \\
\hline 4 & 2.95 & 0.142 & 1.5 \\
\hline 5 & 2.95 & 0.351 & 1.5 \\
\hline 6 & 2.95 & 0.22 & 0.67 \\
\hline 7 & 2.95 & 0.22 & 3.37 \\
\hline
\end{tabular}

Table 1. Cutting conditions in experiment

\section{EXPERIMENTAL RESULTS AND DISCUSSION}

The organization of experimental research gave possibilities for very sort interrupting of the machining process monitoring versus time until tool is worn and determine relationship among them.

The machinability parameters: cutting temperature, cutting forces, surface roughness parameters of single and multi-tooth face mulling cutter are similar if radial and axial throw is very small $(< \pm 0.002 \mathrm{~mm})$ [7]. According to these, experimental results of single tooth cutter can be applied for the multi- tooth milling cutter parameters prediction.

The results of experimental research are presented in the graphical form. In Figure 3 to Figure 6. Are presented cutting temperature $(\theta)$, cutting forces component and arithmetic mean deviation of surface roughness $R_{a}$ and width of flank wear land versus cutting time for different cutting regimes.

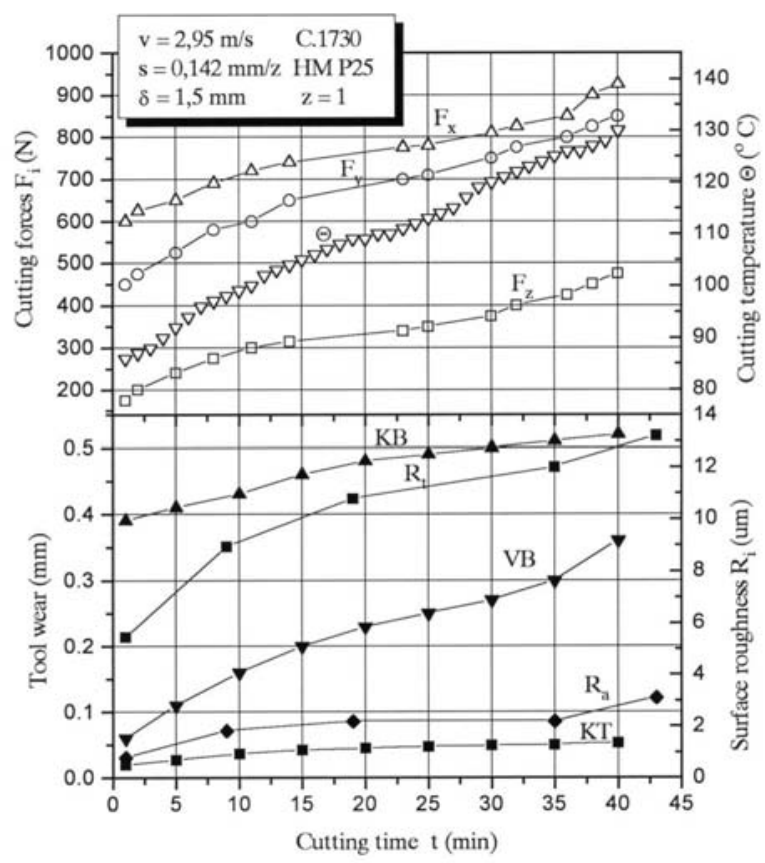

Fig. 3. Cutting force $F_{i}$, surface roughness $R_{i}$, cutting temperature $\theta$ and width of flank wear land versus cutting time 


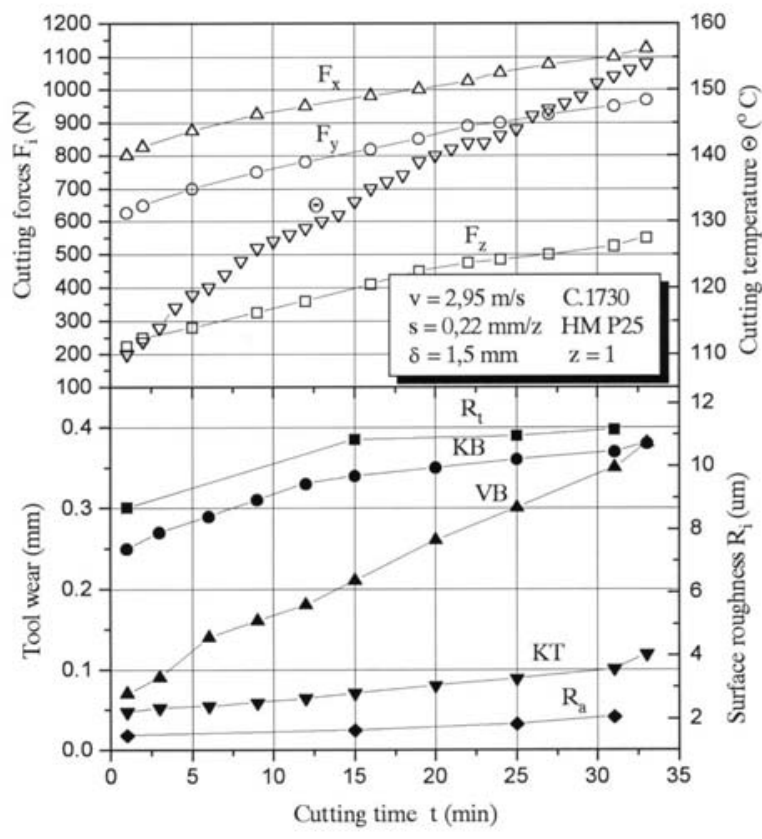

Fig. 4. Cutting force $F_{i}$, surface roughness $R_{i}$, cutting temperature $\theta$ and width of flank wear land versus cutting time

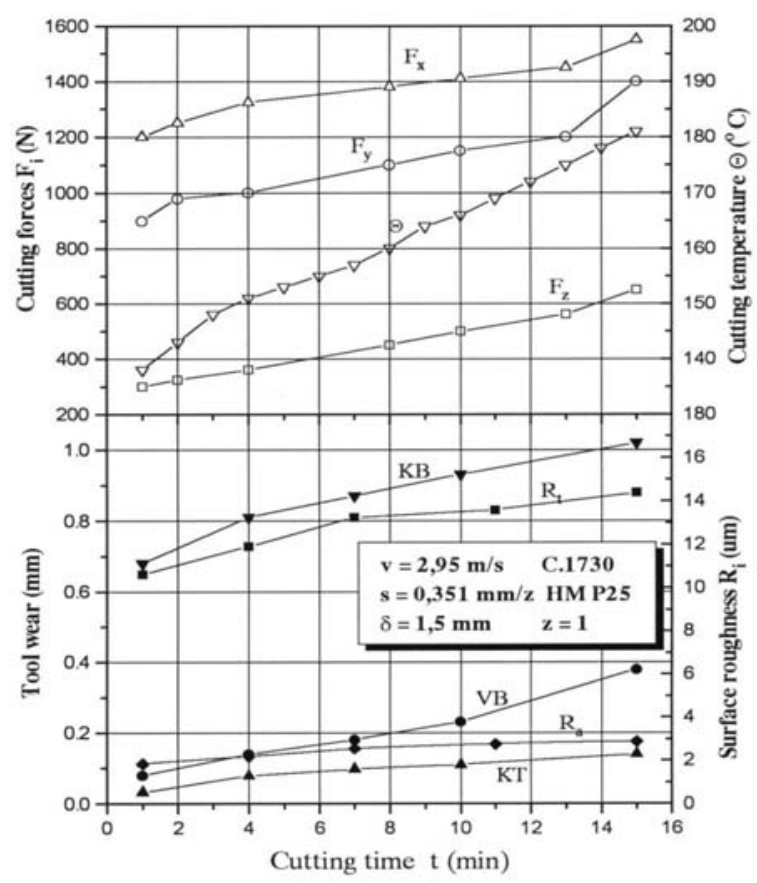

Fig. 5. Cutting force $F_{i}$, surface roughness $R_{i}$, cutting temperature $\theta$ and width of flank wear land versus cutting time

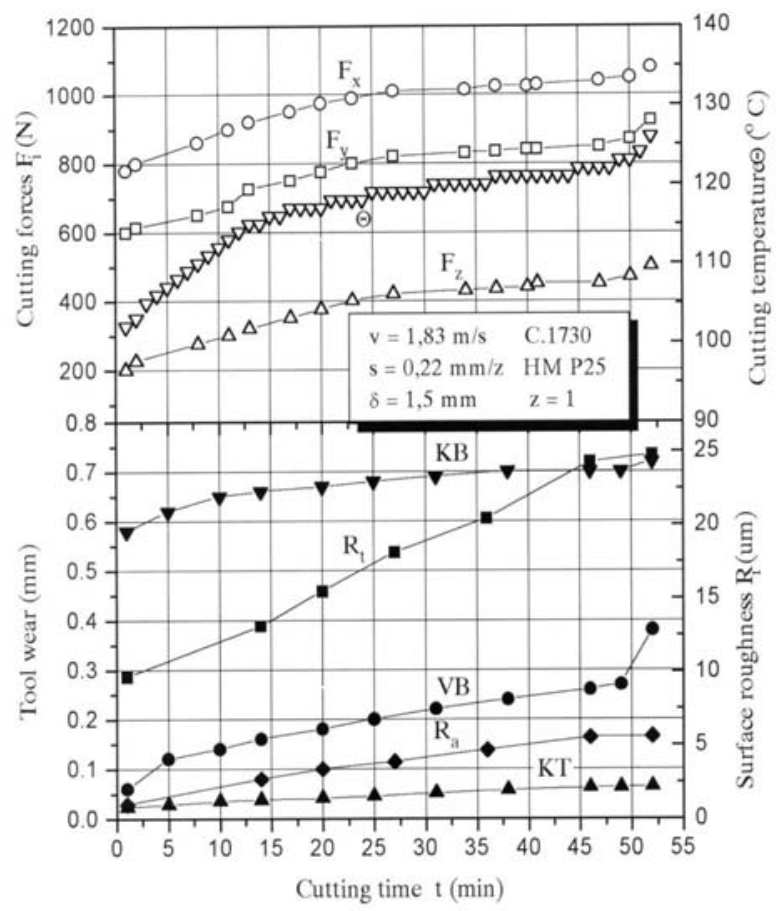

Fig. 6. Cutting force $F_{i}$, surface roughness $R_{i}$, cutting temperature $\theta$ and width of flank wear land versus cutting time

On the bases of the time progression of these parameters and parameters of tool wear time progress it is possible to obtain correlation between cutting temperature $\theta$, cutting force component $F_{x}$, arithmetic mean deviation of profile $R_{a}$ and tool wear. In the paper width of flank wear land VB for these relationships is chosen. Relationship are in linear and with correlation coefficients near one what indicates very strong correlation.

In the Table 2 and Table 3 are constant in correlation.

The sensors for monitoring milling process can be developed based on these correlations.

\section{CONCLUSION}

The following conclusions can be stated:

- Time progression of the machining process parameters is similar to the time progression of width of flank wear land.

- Strong correlation relationships between machining process parameters and width of flank wear land VB were determined.

\begin{tabular}{|r||r|r|r||r|r|r||r|r|r||}
\hline \hline C C & \multicolumn{3}{|c||}{$F_{x}=\mathrm{a}+\mathrm{b} \mathrm{VB}$} & \multicolumn{3}{c||}{$F_{y}=\mathrm{a}+\mathrm{b} \mathrm{VB}$} & \multicolumn{3}{c||}{$F_{z}=\mathrm{a}+\mathrm{b}$ VB } \\
\hline \hline $\mathrm{No}$ & $\mathrm{a}$ & \multicolumn{1}{c|}{$\mathrm{b}$} & \multicolumn{1}{c|}{$\mathrm{R}$} & $\mathrm{a}$ & $\mathrm{b}$ & $\mathrm{R}$ & $\mathrm{a}$ & \multicolumn{1}{c|}{$\mathrm{b}$} & $\mathrm{R}$ \\
\hline \hline 1 & 718.61 & 1251.31 & 0.968 & 501.56 & 1385.55 & 0.975 & 121.90 & 1298.18 & 0.995 \\
\hline 2 & 745.88 & 1028.73 & 0.988 & 559.69 & 1141.59 & 0.995 & 160.81 & 1057.15 & 0.989 \\
\hline 3 & 655.12 & 1690.48 & 0.994 & 587.27 & 1119.05 & 0.979 & 102.74 & 880.95 & 0.995 \\
\hline 4 & 1148.25 & 1101.71 & 0.979 & 770.93 & 1662.12 & 0.999 & 210.08 & 1185.89 & 0.994 \\
\hline 5 & 536.32 & 1043.53 & 0.995 & 376.64 & 1360.76 & 0.997 & 127.02 & 958.41 & 0.993 \\
\hline 6 & 401.23 & 500.56 & 0.996 & 199.57 & 876.20 & 0.997 & 110.05 & 657.37 & 0.999 \\
\hline 7 & 1519.44 & 1831.16 & 0.972 & 1106.0 & 1666.50 & 0.956 & 369.54 & 602.58 & 0.997 \\
\hline
\end{tabular}

Table 2. Correlation coefficient and coefficients equation (1) 


\begin{tabular}{|c||c|c|r||r|r|r||r|r|r||}
\hline \hline \multirow{2}{*}{ C C } & \multicolumn{3}{|c||}{$R_{\mathrm{a}}=\mathrm{c}+\mathrm{d}$ VB } & \multicolumn{3}{c||}{$R_{\mathrm{t}}=\mathrm{c}+\mathrm{d}$ VB } & \multicolumn{3}{c||}{$\Theta=\mathrm{e}+\mathrm{f}$ VB } \\
\hline \hline $\mathrm{No}$ & $\mathrm{c}$ & \multicolumn{1}{c|}{$\mathrm{d}$} & \multicolumn{1}{c|}{$\mathrm{R}$} & \multicolumn{1}{c|}{$\mathrm{c}$} & \multicolumn{1}{c|}{$\mathrm{d}$} & \multicolumn{1}{c|}{$\mathrm{R}$} & $\mathrm{e}$ & \multicolumn{1}{c|}{$\mathrm{f}$} & \multicolumn{1}{c|}{$\mathrm{R}$} \\
\hline \hline 1 & -0.364 & 20.95 & 0.988 & 4.293 & 68.01 & 0.966 & 98.09 & 94.41 & 0.971 \\
\hline 2 & 1.271 & 2.029 & 0.958 & 8.480 & 7.582 & 0.842 & 100.81 & 148.13 & 0.996 \\
\hline 3 & 0.926 & 1.132 & 0.886 & 5.856 & 8.649 & 0.962 & 135.23 & 211.90 & 0.981 \\
\hline 4 & 1.775 & 3.312 & 0.889 & 10.338 & 11.91 & 0.910 & 1130.40 & 139.59 & 0.985 \\
\hline 5 & 0.590 & 6.170 & 0.967 & 4.886 & 22.83 & 0.972 & 75.06 & 156.45 & 0.992 \\
\hline 6 & 1.024 & 3.680 & 0.893 & 6.407 & 15.50 & 0.912 & 58.05 & 178.50 & 0.994 \\
\hline 7 & 0.829 & 6.837 & 0.934 & 7.661 & 22.07 & 0.936 & 178.66 & 160.31 & 0.988 \\
\hline
\end{tabular}

Table 2. Correlation coefficient and coefficients equation (2) and (3)

\section{REFERENCES}

[1] T. Rajasekaran, K. Palanikumar, B.K. Vinayagam, Application of fuzzy logic for modeling surface roughness in turning CFRP composites using CBN tool. PRODUCTION PROCESS DOI 10.1007/s11740-011-0297 (2011)

[2] S.P. Lo, An adaptive-network based fuzzy inference system for prediction of workpiece surface roughness in end milling, Journal of Materials Processing Technology 142 (2003) 665675.

[3] Fu H. J, De Vor R.E, Kapoor S. G. A Mechanistic model for prediction of the force System in Face Milling operations, Journal of Eng. For Ind, Vol 108,1984, pp81-88

[4] J. Balic, M. Korosec, Intelligent tool path generation for milling of free surfaces using neural networks, International Journal of Machine Tools \& Manufacture 42 (2002) 1171-1179.

[5] C.J. Luis Pe'rez, Surface roughness modeling considering uncertainty in measurements, International Journal of Production Research 40 (10) (2002) 2245-2268.

[6] Kovac P., Milikic D. Correlation between temperature and tool wear, Proc of CSME Mech
Eng. Forum, Vol 3, Toronto, 1990, pp283-288

[7] Kovac P. Tool life and temperature of single/tooth and multi/tooth milling cutter. Proc of International res ICPR, Hafei, 1992, pp2055-2058

\section{ACKNOWLEDGMENT}

This paper is the result of the research within the project TR 35015 financed by the Ministry of Science and Technological Development of the Republic of Serbia

Authors: ${ }^{1}$ Professor Pavel Kovac PhD, ${ }^{1}$ Assist. Professor Borislav Savkovic PhD, ${ }^{1}$ MSc Dragan Rodic, ${ }^{2}$ Professor Dušan Ješić PhD.

${ }^{1}$ University of Novi Sad, Faculty of Technical Sciences, Institute for Production Engineering, Trg Dositeja Obradovica 6, 21000 Novi Sad, Serbia, Phone.: +381 21 450-366, Fax: +381 21 454-495.

${ }^{2}$ MTM Academia, Novi Sad, Serbia.

E-mail: pkovac@uns.ac.rs savkovic@uns.ac.rs rodicdr@uns.ac.rs dusanjesic@hotmail.com 